\title{
On Investment Law and Questions of Change
}

\author{
Joshua Paine \\ Max Planck Institute Luxembourg for International, European and Regulatory \\ Procedural Law, Luxembourg \\ josh.painer@gmail.com
}

\begin{abstract}
This article analyses the various ways in which investment law raises questions of change. It distinguishes between changes in international investment norms, and changes in a host state's regulatory system which is subject to the control of such norms, and explains how these different manifestations of change relate to the distinct yet interrelated issues of interpretation and application. The article explains why, given features of the contemporary investment regime, on questions of interpretation, concerning the content of international investment norms, arbitrators operate within wider processes of law-development over which states, as treaty masters, also exercise significant influence. In contrast, arbitrators dominate the process of applying international investment norms to particular investor-state disputes to determine whether changes in a host state's regulatory system breach applicable investment norms. This claim is demonstrated in relation to the two most prominent investment treaty standards: fair and equitable treatment, and the protection against indirect expropriation.
\end{abstract}

\section{Keywords}

change - development of international law - distinction between interpretation and application - fair and equitable treatment - indirect expropriation - stability - treaty drafting

* Thanks to two anonymous reviewers for helpful comments on an earlier version of this article. Some of the ideas further developed in this article were initially conceived within a broader doctoral project entitled 'International Adjudicatory Functions: A Comparative Study through the Lens of Environmental Cases' (University of Melbourne, 2016). An abstract of the project is available at $<\mathrm{http}$ ://hdl.handle.net/11343/123762> accessed 7 July 2017. I wish to acknowledge the contribution of my supervisors, Professor Anne Orford and Associate Professor Margaret Young. 
It is often observed that investment law, and specifically the application of treaty disciplines by arbitral tribunals, involves a challenge of balancing a host state's interest in being able to adapt regulation to changing circumstances with an investor's interest in knowing in advance the regulatory system that will apply to its investment. ${ }^{1}$ The large number of pending or decided cases concerning states' changes to incentive schemes for various forms of renewable energy can accurately be described in such terms. ${ }^{2}$ At the same time, one can analyse broader processes of change within norms of investment law, for example by tracing innovations developed by arbitral tribunals and reactions by states as treaty parties, and vice versa. ${ }^{3}$ This article aims to provide conceptual clarity and context to the observation that investment law, and specifically investment arbitration, often involves managing questions of change. The

1 Moshe Hirsch, 'Between Fair and Equitable Treatment and Stabilization Clause: Stable Legal Environment and Regulatory Change in International Investment Law' (2011) 12(6) JWIT 783, 783-84; Andrew Newcombe, 'The Boundaries of Regulatory Expropriation in International Law' (2005) 20 ICSID Rev-FILJ 1, 45; Vaughan Lowe, 'Regulation or Expropriation?' (2002) 55 CLP 447, 447, 464; Kyla Tienhaara, 'Unilateral Commitments to Investment Protection: Does the Promise of Stability Restrict Environmental Policy Development?' (2007) 17 YB Intl Env L 139, 157 ("The key problem with state contracts, and investment law in general, is the need to balance the legitimate need of the investor for stability with the legitimate need of the regulator for flexibility to respond to changing values, risks, and circumstances'). For recognition of this point in arbitral jurisprudence see eg Total $S A v$ Argentina, ICSID Case No ARB/04/1, Decision on Liability (27 December 2010) para 123; El Paso Energy Int'l Co $v$ Argentina, ICSID Case No ARB/03/15, Award (31 October 2011) para 358; see also Anne van Aaken, 'International Investment Law Between Commitment and Flexibility: A Contract Theory Analysis' (2009) 12 JIEL 507 (suggesting from the perspective of contract theory that international investment law, including arbitral interpretation, involves finding an optimal balance between commitment to the agreed bargain and flexibility in the face of future unforeseeable circumstances).

2 Daniel Behn and Malcolm Langford, "Trumping the Environment? An Empirical Perspective on the Legitimacy of Investment Treaty Arbitration' (2017) 18(1) JWIT 14, 39; Björn Arp, 'Charanne BV v Spain' (2016) 110 AJIL 327, 332-33.

3 See eg W Michael Reisman, 'Canute Confronts the Tide: States versus Tribunals and the Evolution of the Minimum Standard in Customary International Law' (2015) 30 ICSID Rev-FILJ 616; Anthea Roberts, 'Power and Persuasion in Investment Treaty Interpretation: The Dual Role of States' (2010) 104 AJIL 179; M Sornarajah, Resistance and Change in the International Law on Foreign Investment (CUP 2015) (also emphasising the influence of nongovernmental organizations and academics); Alec Stone Sweet, Michael Yunsuck Chung and Adam Saltzman, 'Arbitral Lawmaking and State Power: An Empirical Analysis of InvestorState Arbitration' (forthcoming) JIDS. 
article makes two key contributions. First, it distinguishes between changes in international investment norms, and changes in a host state's regulatory system which is subject to the control of such norms, and explains how these different manifestations of change relate to the distinct yet interrelated tasks of interpretation and application. I explain why, given various features of the contemporary investment regime, on questions of interpretation, concerning the content of international investment norms as a general matter, arbitrators operate within wider processes of law-development over which states, as treaty drafters and treaty parties, also exercise significant influence. In contrast, arbitrators dominate the process of applying international investment norms to particular investor-state disputes, and determining whether changes in a host state's regulatory system breach relevant investment norms. Second, this article traces the two different senses in which questions of change frequently arise - namely changes in the content of international investment norms and changes in a host state's regulatory system which is subject to the control of such norms - in relation to the two most prominent standards of investment protection: fair and equitable treatment (FET), and the protection against indirect expropriation without compensation. While arbitrators have made notable contributions to changes in the content of these norms as a general interpretive matter, states have engaged in widespread reform through treaty drafting over the last decade, often as a direct response to prior arbitral interpretations. ${ }^{4}$ Yet such treaty-based reforms have only partially curtailed the room for arbitrators to clarify and develop the meaning of key investment norms through the process of interpretation. Furthermore, so long as investors are provided with access to investor-state arbitration, arbitrators are likely to retain a dominant role in applying treaty disciplines to particular disputes. Applying the FET and indirect expropriation standards frequently requires arbitrators to determine the permissible margin of regulatory change within the host state.

This article proceeds as follows: Part 2 provides a brief overview of previous attempts to conceptualise the tension between stability and change in investment law and international law more generally. It introduces the distinction

4 Eric De Brabandere, 'States' Reassertion of Control over International Investment Law: (Re)Defining "Fair and Equitable Treatment" and "Indirect Expropriation"' in Andreas Kulick (ed), Reassertion of Control over the Investment Treaty Regime (CUP 2016) 285, 308; Jürgen Kurtz, 'Building Legitimacy Through Interpretation in Investor-State Arbitration: On Consistency, Coherence, and the Identification of Applicable Law' in Zachary Douglas, Joost Pauwelyn and Jorge E Viñuales (eds), The Foundations of International Investment Law: Bringing Theory into Practice (OUP 2014) 257, 273. 
between interpretation and application, and explains why, given various features of the investment regime, the relative influence of arbitrators and states differs markedly at these two levels. Part 3 turns to the FET standard. It examines changes in the content of the norm, and specifically its requirement of a degree of stability in the host state's regulatory system, brought about both through more balanced arbitral interpretations and recent treaty-drafting innovations (3.1). It then analyses arbitrators' application of the FET standard in several recently decided cases which have prominently raised its 'stability' element, to support the argument that in applying the standard adjudicators determine the permissible margin of regulatory change in the host state (3.2). Part 4 focuses on the indirect expropriation standard. At the level of interpretation, it suggests that arbitrators have made certain notable contributions to the meaning of the norm over the last decade through the development of a police powers doctrine, however significant changes have also occurred through states' efforts as treaty drafters to refine the meaning of the standard (4.1). It then demonstrates that in applying the indirect expropriation standard in specific disputes arbitrators often determine the permissible degree of host state regulatory change (4.2). Part 5 concludes.

2

\section{Clarifying Different Types of Change: The Distinction Between Interpretation and Application}

The challenge of ensuring legal certainty through predictable interpretation of the law and at the same time ... [making] allowance for legal change, without which law cannot live, ${ }^{5}$ has a long pedigree in thinking about the role of international adjudication within the international legal order, which predates the rise of investment arbitration. ${ }^{6}$ For present purposes, however, it is sufficient to begin with the contribution of Thomas Franck, who, writing in

5 Ilmar Tammelo, Treaty Interpretation and Practical Reason: Towards a General Theory of Legal Interpretation (Law Book Company 1967) 53.

6 The most important analyses are Hersch Lauterpacht, The Function of Law in the International Community (OUP 1933) 245-59, and generally pt iv ('Stability and Change in International Law'); C Wilfred Jenks, 'Economic and Social Change and the Law of Nations' (1973) 138 Collected Courses of the Hague Academy of International Law 455; Wilfred Jenks, 'Orthodoxy and Innovation in the Law of Nations' (1971) 57 Proceedings of the British Academy 215. Messenger has recently provided a sophisticated account focused on the broader question of explaining change in international law, with specific application to World Trade Organization law, see Gregory Messenger, The Development of World Trade Organization Law: Examining Change in International Law (OUP 2016). Messenger briefly discusses, at ibid 4, the tension 
the 1990s, suggested that the tension between stability and change within the international legal order was managed through the 'rubric' of fairness, with substantive fairness, understood as distributive justice, favouring change, and procedural fairness, or right process, favouring 'stability and order. ${ }^{7}$ Notably, Franck applied this framework to investment law, suggesting that a host state's 'demand for change' and investors' 'insistence on stability' was 'likely to reach the public arena as a dispute about the fairness of law'. 8 The discourse could be specific to a dispute before an arbitral tribunal, or it could be 'general and normative' at the level of treaty negotiations or debate in other law-developing fora. Either way, it would be 'about balancing the social need to induce capital growth against political claims to redistributive justice', to give the compact between investors and host governments 'the elasticity needed to accommodate the inevitable tension between the political pull to change and the economic rationale for stability'. ${ }^{9}$

Roland Kläger, building on Franck's work, presents an account of the FET standard as an embodiment of justice, whereby arguments favouring stability or right process are 'found mainly in the lines of jurisprudence of arbitral tribunals, such as fair procedure, non-discrimination, the protection of the investor's legitimate expectations and transparency'. In contrast: '[a]rguments ... for redistributive change ... may be subsumed under the notion of state sovereignty, entitling a state to pursue different tax, currency, labour, social or other policies', as well as 'the label of sustainable development', which Kläger understands as encompassing social or ecological considerations foregrounded by human rights and environmental law. ${ }^{10}$ Again, the key claim is that in applying the FET standard arbitrators must balance competing considerations, some favouring stability and others favouring change. ${ }^{11}$ This reflects that FET is, according to Kläger, 'a sophist norm' rather than a hard and fast rule, meaning part of the fairness discourse, or balancing of competing considerations, occurs at the law-application stage. ${ }^{12}$

\footnotetext{
between stability and change noting it 'creates numerous challenges for those concerned with the effective functioning of a legal system'.

7 Thomas M Franck, Fairness in International Law and Institutions (OUP 1998) 7.

8 ibid 441.

9 ibid.

10 Roland Kläger, 'Fair and Equitable Treatment' in International Investment Law (CUP 2011) $148-53$.

11 Roland Kläger, 'Fair and Equitable Treatment: A Look at the Theoretical Underpinnings of Legitimacy and Fairness' (2010) 11(3) JWIT 435, 452-55.

12 ibid 447-48, 452.
} 
Martti Koskenniemi, consistent with his broader claims concerning the indeterminacy of legal argument, has argued that the tendency to speak of balancing stability and change 'restates the problem' because choosing between competing claims of stability and change requires evaluating 'what is equitable in certain circumstances and what is not.' ${ }^{13}$ For Koskenniemi, any choice between apparently opposing arguments favouring stability and change must rely on an external criterion of justice as no general legal rule exists which could resolve the matter in a way that is not open to competing, equally legally plausible arguments..$^{14}$ Koskenniemi is correct that any question of deciding between or balancing competing claims of stability and change has to be understood within the circumstances of a particular case, and doctrine cannot provide a general rule which would resolve the issue in a definitive way for future cases.${ }^{15}$ Indeed, contemporary arbitrators consistently stress that key investment standards which impact questions of regulatory change must be understood in a fact-specific manner and do not admit of definitive statements. ${ }^{16}$ Koskenniemi's discussion reminds us that the question in any particular dispute is stability or change for whom and for which interests. ${ }^{17}$

13 Martti Koskenniemi, From Apology to Utopia: The Structure of International Legal Argument (reissue, CUP 2005) 452-55.

14 ibid 452-61.

15 ibid 451, 457, 461.

16 See eg Chemtura Corporation (formerly Crompton Corporation) $v$ Canada, UNCITRAL (NAFTA), Award (2 August 2010) para 294 (noting in regard to indirect expropriation "The determination of whether there has been a "substantial deprivation" is a fact-sensitive exercise to be conducted in the light of the circumstances of each case'); Waste Management, Inc v Mexico, ICSID Case No ARB(AF)/oo/3, Award (30 April 2004) para 99 (FET standard 'to some extent a flexible one which must be adapted to the circumstances of each case'); Merrill \& Ring Forestry LP v Canada, ICSID (NAFTA), Award (31 March 2010) para 210 ('the concepts of fairness, equitableness and reasonableness cannot be defined precisely: they require to be applied to the facts of each case'); Continental Casualty Cov Argentina, ICSID Case No ARB/03/9, Award (5 September 2008) para 255 (content of the FET obligation 'varies in part depending on the circumstances in which the standard is invoked: the concept of fairness being inherently related to keeping justice in variable factual contexts').

17 Koskenniemi (n 13) 461 (noting the question is 'what kind of and whose consent it is that counts and which kind of teleology it is that is working' - emphasis in the original); Todd Weiler, 'Who, Then, Shall Judge? The Interpretation of International Investment Agreements and the Rule of International Law' in Arthur W Rovine (ed), Contemporary Issues in International Arbitration and Mediation: The Fordham Papers 2013 (Brill Nijhoff 2015) 299, 329-30. 
At this point it is useful to distinguish between the concepts of interpretation and application. Whereas interpretation refers to determining the meaning of a rule', application is the process of 'determining the consequences which the rule attaches to the occurrence of a given fact.'. ${ }^{18}$ It is important to distinguish interpretation and application because, for a variety of reasons which will be considered shortly, the relative influence of investment arbitrators and states within these two processes differs markedly. That said, it must be remembered that the exercises of interpretation and application are never fully separate, ${ }^{19}$ particularly in the case of open-textured and evaluative norms such as FET where the content of the norm, a matter of interpretation, is partly elaborated through its application to specific factual scenarios, ${ }^{20}$ a task largely undertaken by arbitrators. ${ }^{21}$

On questions concerning the interpretation, or meaning in general, of investment norms, states have in recent years engaged in widespread clarification and reform of investment protection standards through treaty drafting, although, as we will see, these efforts have not been entirely successful in removing ambiguities regarding the content of such standards and thus curtailing arbitral discretion. ${ }^{22}$ Furthermore, recent investment treaties frequently provide for interstate committees empowered to adopt binding interpretations

18 Case Concerning the Factory at Chorzów (Germany v Poland) (Claim for Indemnity Jurisdiction) [1927] PCIJ Rep Series A No 9 (Diss Op Ehrlich) 39; similarly: 'Draft Convention on the Law of Treaties: Comment to Article 19', reprinted in (1935) 29 Supplement to the AJIL 938. For further discussion and references see Anastasios Gourgourinis, 'The Distinction Between Interpretation and Application of Norms in International Adjudication' (2011) 2 JIDS 31, 43-48.

19 Roberts (n 3$) 179$.

20 Reisman (n 3 ) 617-18; See above text at $n n 12$ and 16.

21 Arguably, this captures precisely what is problematic about the standard-like nature of key investment norms, namely that the content of the norm governing states' behavior only becomes clear at a later time, when the norm is applied by adjudicators in a specific dispute, see Federico Ortino, 'Refining the Content and Role of Investment "Rules" and "Standards": A New Approach to International Investment Treaty Making' (2013) 28 ICSID Rev-FILJ 152, 153-58.

22 As Yackee has suggested, a limitation of better treaty drafting as a reform strategy is that 'states are unlikely to be able to draft, once and for all, a perfectly controlling treaty' text, including due to the inherent ambiguity of language and the inability to predict all future scenarios, see Jason Webb Yackee, 'Controlling the International Investment Law Agency' (2012) 53 Harv Intl L J 391, 424. For overviews of such treaty-drafting reforms, see Caroline Henckels, 'Protecting Regulatory Autonomy Through Greater Precision in Investment Treaties: The TPP, CETA, and TTIP' (2016) 19 JIEL 27; UNCTAD, 'Taking Stock of IIA Reform' (IIA Issues Note No 1, 2016). 
of the agreements, ${ }^{23}$ and states have demonstrated some willingness to utilise these mechanisms in order to correct arbitral interpretations. ${ }^{24}$ States also frequently exercise their ability-increasingly provided for explicitly in investment treaties - to make submissions as a non-disputing treaty party on the interpretation of their treaties. ${ }^{25}$ Thus, on questions concerning the interpretation of

23 See eg Comprehensive Economic and Trade Agreement Between Canada and the European Union (signed 30 October 2016, not yet in force) arts 8.31(3), 8.44(3)(a) (CETA) <http://ec.europa.eu/trade/policy/in-focus/ceta/ceta-chapter-by-chapter/>; Trans-Pacific Partnership Agreement (signed 4 February 2016, not yet in force) art 27.2(2)(f) (TPP) <https://ustr.gov/trade-agreements/free-trade-agreements/trans-pacific -partnership/tpp-full-text> all accessed 11 September 2017. For a list of other treaties which include such a provision, and analysis of how such mechanisms vary, see Kathryn Gordon and Joachim Pohl, 'Investment Treaties over Time - Treaty Practice and Interpretation in a Changing World' OECD Working Papers on International Investment 2015/02 (2015) 26-29; see also David Gaukrodger, 'The Legal Framework Applicable to Joint Interpretive Agreements of Investment Treaties' OECD Working Papers on International Investment 2016/01 (2016) 5 (noting such provisions increasingly appear in recent treaties but the vast majority of investment treaties do not address joint interpretive action). In the absence of such a mechanism, the treaty parties' subsequent agreement, or subsequent practice establishing agreement, regarding the interpretation of a treaty must nevertheless be taken into account under standard rules of treaty interpretation: Vienna Convention on the Law of Treaties (opened for signature 23 May 1969, entered into force 27 January 1980) 1155 UNTS 331 (VCLT) arts 31(3)(a), (b). The International Law Commission, in its ongoing work on this topic, takes the view that these 'authentic means of interpretation' are 'not necessarily conclusive, but more or less authoritative' in the overall exercise of treaty interpretation, see the Commission's Conclusion 3 [2] and commentary thereto, which it has adopted on a first reading: 'Report of the International Law Commission Sixty-eighth Session' (2016, UN Doc. A/71/10) 132-137.

24 The most famous example is NAFTA Free Trade Commission, 'Notes of Interpretation of Certain Chapter 11 Provisions' (31 July 2001) <www.sice.oas.org/tpd/nafta/Commission/ CHuunderstanding_e.asp $>$ accessed 11 September 2017. See also below $\mathrm{n} 39$.

25 In addition to being included in more recent US and Canadian investment treaties, such a right appears in Article 1128 of NAFTA and has been frequently utilised by nondisputing state parties given their long-term interest in the interpretation of that treaty, see Gabrielle Kaufmann-Kohler, 'Non-Disputing State Submissions in Investment Arbitration: Resurgence of Diplomatic Protection?' in Laurence Boisson de Chazournes, Marcelo G Kohen and Jorge E Viñuales (eds), Diplomatic and Judicial Means of Dispute Settlement (Martinus Nijhoff 2013) 307, 312-15. Kaufmann-Kohler considers the basis for allowing non-disputing state submissions where the underlying investment treaty does not provide for such a right, noting that there is a strong rationale for allowing such submissions on questions of treaty interpretation, but not on the application of the treaty to the specific facts of the investor-state dispute concerned, ibid 319-26. See also UNCITRAL Rules on Transparency in Treaty-based Investor-State Arbitration (effective as of 1 April 2014) art $5<$ www.uncitral.org/pdf/english/texts/arbitration/rules-on 
investment treaties, arbitrators operate within wider processes of law-development, alongside states as treaty masters. Or, as Anthea Roberts puts it, the delegation of interpretive power from treaty parties to tribunals is partial, and treaty interpretation involves an ongoing dialogue between these two sets of actors. $^{26}$ An important aspect of this process of dialogue is that arbitrators' interpretations of investment treaty provisions frequently have some influence on future treaty-making. ${ }^{27}$ 'Influence' in this sense can range anywhere between arbitral interpretations being codified wholesale in subsequent treaty drafting and arbitral interpretations being overridden by disgruntled treaty parties. ${ }^{28}$

In contrast, investment treaties largely do not enable states, as treaty parties, to determine the application of relevant standards of investment protection to particular investor-state disputes. Of course, many investment treaties allow the authorities of the treaty parties, if they agree, to determine the application of the treaty to investor claims concerning taxation or prudential measures. ${ }^{29}$

-transparency/Rules-on-Transparency-E.pdf $>$ accessed 11 September 2017. For proposals as to how such mechanisms could be developed to provide treaty parties with greater control over law-development within the regime, see Yackee (n 22) 434-44 (suggesting that treaty parties might be given an opportunity to comment on draft awards, or to jointly veto the law-making effects of an award).

26 Roberts (n 3) 180, 193-94.

27 Catharine Titi, 'The Arbitrator as a Lawmaker: Jurisgenerative Processes in Investment Arbitration' (2013) 14(5) JWIT 829, 843. Note also that pending cases, yet to be decided, can influence states' treaty drafting choices. One example of this is the 'carve-out' for tobacco control measures included in the TPP (n 23) art 29.5. This would appear to be a response to the investor claims brought against Australia and Uruguay in relation to such measures. At the time the TPP negations were concluded in October 2015, and the text publicly released shortly afterwards, both claims were pending. Both claims were subsequently dismissed: Philip Morris Asia Ltd v Commonwealth of Australia, PCA Case No 2012-12, Award on Jurisdiction and Admissibility (17 December 2015); Philip Morris Brands Sàrl, Philip Morris Products SA and Abal Hermanos SA v Uruguay ICSID Case No ARB $/ 10 / 7$, Award (8 July 2016).

28 Christoph Schreuer, 'The Development of International Law by ICSID Tribunals' (2016) 31 ICSID Rev-FILJ 728, 737 (distinguishing between instances where treaty drafters take guidance from tribunal practices, instances where drafters seek to settle questions left open by prior conflicting decisions, and instances where drafters seek to counteract undesirable arbitral tendencies).

29 See eg US Model BIT (2012) arts 20(3) and (4), 21(2) <https://ustr.gov/sites/default/ files/BIT\%2otext\%2ofor\%2oACIEP\%2oMeeting.pdf>; Free Trade Agreement Between Canada and Peru (signed 29 May 2008, entered into force 1 August 2009) arts 819(2), $820(2), 823(4), 2203(8)<$ http://international.gc.ca/trade-commerce/trade-agreementsaccords-commerciaux/agr-acc/peru-perou/fta-ale/index.aspx?lang=eng>; Free Trade Agreement Between the Government of New Zealand and the Government of the 
However, very few treaties have broadened this mechanism to cover a wider range of measures, ${ }^{30}$ and, in any case, its activation relies on the treaty parties reaching agreement, which will not always be forthcoming. In short, investment arbitrators dominate the process of applying treaty standards to specific, fact-intensive investor-state disputes. Thus, to cite Roberts again, as regards the role of applying investment treaty standards to specific investor-state disputes investment treaty tribunals are 'trusteelike' relatively independent international tribunals, whereas in relation to interpreting investment treaties and developing the law as a general matter the same tribunals are more 'agentlike', subject to potential override by the treaty parties. ${ }^{31}$

Building on the above distinction between interpretation and application, we can distinguish between arbitrators as actors within broader processes of change in investment treaty norms, and arbitrators as managers of change within the regulatory system of a host state which is subject to the applica-

People's Republic of China (signed 7 April 2008, entered into force 1 October 2008) art 204(4) <http://investmentpolicyhub.unctad.org/Download/TreatyFile/2564> all accessed 11 September 2017. Under such provisions where a joint determination of the competent authorities of the treaty parties occurs, the determination typically binds tribunals, or the investor is barred from brining a claim or relying on certain treaty provisions. For discussion and further references see Gordon and Pohl (n 23) 29-31.

One recent example is the Free Trade Agreement Between the Government of Australia and the Government of the People's Republic of China (signed 17 June 2015, entered into force 20 December 2015) [2015] ATS 15. The treaty provides in Article 9.11.4 that 'measures of a Party that are non-discriminatory and for the legitimate public welfare objectives of public health, safety, the environment, public morals or public order shall not be the subject of a claim' by an investor. If a respondent state receives a request for consultations from an investor which the state believes is a claim covered by Article 9.11.4, it can issue a notice which triggers a 9o-day consultation period with the other treaty party, see art 9.11.5-6. If the treaty parties agree that the measure concerned is one covered by the exception in Article 9.11.4, their decision binds a tribunal, see art 9.18(3). See also Anthea Roberts and Richard Braddock, 'Protecting Public Welfare Regulation Through Joint Treaty Party Control: A ChAFTA Innovation' Columbia FDI Perspectives No 176 (20 June 2016) (highlighting the novelty of this mechanism).

Roberts (n 3) 188; see also Andreas Kulick 'Reassertion of Control: An Introduction' in Kulick (n 4) 18-21. For discussion of the distinction between delegation to agents and trustees, and its application to international tribunals, see Karen J Alter, 'Agents or Trustees? International Courts in Their Political Context' (2008) 14 EJIR 33, 38-47; Roberts (n 3) 186-87; Alec Stone Sweet and Thomas L Brunell, 'Trustee Courts and the Judicialization of International Regimes: The Politics of Majoritarian Activism in the European Convention on Human Rights, the European Union, and the World Trade Organization' (2013) 1 J L \& Courts 61, 64-67; Alec Stone Sweet and Florian Grisel, The Evolution of International Arbitration:Judicialization, Governance, Legitimacy (OUP 2017) 22-32. 
tion of such norms. Several structural features of the investment regime, as it currently exits, help explain why the relative influence of arbitral tribunals differs at these two levels. The influence of arbitrators over the interpretation, or meaning in general, of investment treaty norms is substantially reduced by the decentralised and bilaterally constructed nature of the regime. The decision of states to (so far) utilize ad hoc tribunals, and avoid creating any permanent tribunal or appellate mechanism reduces the relative influence of any one tribunal over law-development within the regime. ${ }^{32}$ The fact that investment treaties differ in material respects also leads to arbitrators having less influence over issues of law-development than adjudicators within multilateral regimes which rely on common underlying texts. Furthermore, because investment treaties are generally bilateral or, less commonly, narrow plurilateral, agreements, it is more likely that the treaty parties will be able to override arbitral interpretations through authoritative interpretations, or treaty amendments, than in large multilateral settings. In all of the above respects the position of investment arbitrators can usefully be contrasted with that of the WTO Appellate Body: in that regime, the inability of a diverse membership to agree upon authoritative interpretations or amendments means that in practice the Appellate Body - a tribunal characterised by significant continuity including because of its powerful secretariat - has the final say on the meaning of the common covered agreements. ${ }^{33}$

A distinction should, however, be drawn between the influence over treaty interpretation of particular investment treaty tribunals and that of investment treaty tribunals collectively. The latter, which has largely been staffed by a small number of frequently appointed arbitrators, ${ }^{34}$ has had an unprecedented number of opportunities to determine the meaning of the same or similar treaty provisions and has driven the emerging 'jurisprudence constante' of the regime. ${ }^{35}$ Thus, if one focuses on investment treaty tribunals collectively,

32 Santiago Montt, State Liability in Investment Treaty Arbitration: Global Constitutional and Administrative Law in the BIT Generation (Hart 2009) 157-59.

33 Other commentators have also noted that the small number of principals or treaty parties in the investment context means that there is much more potential for political override of adjudicators' decisions than in large multilateral settings such as the WTO, see eg Jacob Katz Cogan, 'Competition and Control in International Adjudication' (2008) 48 Virginia J Intl L 411, 431; Tom Ginsburg, 'Political Constraints on International Courts' in Cesare PR Romano, Karen J Alter and Yuval Shany (eds), The Oxford Handbook of International Adjudication (OUP 2013) 483, 496.

34 See eg Sergio Puig, 'Social Capital in the Arbitration Market' (2014) 25 EJIL 387.

35 Andrea K Bjorklund, 'Investment Treaty Arbitral Decisions as Jurisprudence Constante' in Colin B Picker, Isabella D Bunn and Douglas W Arner (eds), International Economic 
rather than particular ad hoc tribunals, the relative influence of adjudicators over ongoing processes of interpretation would rival and perhaps even surpass that of treaty parties collectively. The use of permanent appellate tribunals, as included in a few recent investment treaties, ${ }^{36}$ and the possible creation of a multilateral investment court, ${ }^{37}$ has the potential to increase adjudicators' relative influence over issues of interpretation by reducing the number of conflicting adjudicatory views. Permanent tribunals can also build up their 'semantic authority', or ability to shape legal discourse given their institutional reputation, over time. ${ }^{38}$ Yet much will depend upon the range of investment treaties over which states choose to give any permanent tribunal jurisdiction, and the extent to which investors choose to bring cases to such a tribunal. To the extent that substantive investment law continues to be characterised by bilateral or narrow plurilateral treaties substantial scope for treaty party override will remain, notwithstanding any use of permanent tribunals. Indeed, at the same time as committing to 'work expeditiously towards the creation of' a multilateral investment court, Canada and the European Union signalled their intention to take very seriously their future role in monitoring and attempting to control adjudicators' interpretations. ${ }^{39}$

Law: The State and Future of the Discipline (Hart 2008) 265-80; Stone Sweet, Chung and Saltzman (n 3) (also emphasising the disproportionate role played by a small number of repeat arbitrators in developing precedent within the investment treaty system).

36 CETA (n 23) arts 8.27-8.30; EU-Vietnam Free Trade Agreement (Agreed Text of January 2016, not yet signed nor in force) ch 8(II) ('Investment'), s 3(4), arts 12-14<http://trade. ec.europa.eu/doclib/docs/2016/february/tradoc_154210.pdf> accessed 20 October 2017.

The EU and Canada have recently initiated discussions with other states regarding the creation of such a court. For a list of relevant developments and documents see European Commission, 'The Multilateral Investment Court Project' < http://trade.ec.europa.eu/ doclib/press/index.cfm?id=1608 $>$ accessed 20 October 2017.

38 For the concept of semantic authority, see Ingo Venzke, How Interpretation Makes International Law: On Semantic Change and Normative Twists (OUP 2012) 63. Apart from the semantic authority of a tribunal as an institution, ad hoc tribunals can obviously draw upon the reputation-based authority of individual members but this is also true of permanent tribunals.

39 Council of the European Union, 'Joint Interpretive Instrument on the Comprehensive Economic and Trade Agreement (CETA) Between Canada and the European Union and its Member States' Doc 13541/16 (27 October 2016) paras 6(e) (stating the treaty parties are 'committed to using these provisions to avoid and correct any misinterpretation of CETA by Tribunals'), and 6(i). For another discussion of the potential for any shift to permanent tribunals to increase the relative power of adjudicators, and the consequent need to for treaty parties to consider a range of control mechanisms, including joint interpretations, see Mark Feldman, 'Investment Arbitration Appellate Mechanism Options: Consistency, 
Beyond its structural features, the aims or telos of the investment treaty regime also explain why arbitrators play a prominent role in applying treaty norms, and deciding on the permissible degree of change within the host state's regulatory system, in particular disputes. Although ensuring stability in the host state's regulatory system is not an explicit aim of most investment treaties, ${ }^{40}$ it is clear that the BIT regime was designed to exercise a degree of control over public decision-making in developing, capital-importing states, as a means of attracting foreign investment flows and ultimately promoting the economic development of the treaty parties. ${ }^{41}$ Consistent with this aim, the substantive norms of the regime cut deeply into host states' sovereign regulatory sphere and apply to an extremely wide range of conduct. As we will see in relation to the FET and indirect expropriation standards, by applying such norms to particular disputes, arbitrators play a key role in deciding upon the 'the proper allocation of risk in the modern regulatory state. ${ }^{42}$ Such determinations go to the heart of the governance function performed by investment treaty arbitration in developing acceptable standards of host state conduct. ${ }^{43}$

Accuracy, and Balance of Power' (2017) ICSID Rev-FILJ (forthcoming) < doi:10.1093/ icsidreview/sixoog>.

Jonathan Bonnitcha, 'Investment Treaties and Transition from Authoritarian Rule' (2014) 15(5-6) JWIT 965, 966-68. Some older US BITs mention regulatory stability in their preambles, see eg Treaty Between United States of America and the Argentine Republic Concerning the Reciprocal Encouragement and Protection of Investment (signed 14 November 1991, entered into force 20 October 1994) <http://investmentpolicy hub.unctad.org/Download/TreatyFile/127> accessed 11 September 2017. See, however, Continental Casualty ( $\mathrm{n} 16$ ) para 258 (interpreting the US-Argentina BIT and holding that stability is not itself an objective of the Treaty but a 'precondition for one of the two basic objects of the Treaty, namely the promotion of the investment flow, rather than being related to its other objective, that of granting protection for investments').

Federico Ortino, 'The Investment Treaty System as Judicial Review' (2013) 24 Am Rev Intl Arb 437, 440-44; Jeswald W Salacuse and Nicholas P Sullivan, 'Do Bits Really Work: An Evaluation of Bilateral Investment Treaties and Their Grand Bargain' (2005) 46 HILJ 67, 77; Kenneth J Vandevelde, Bilateral Investment Treaties: History, Policy, and Interpretation (OUP 2010) 3-4; Marc Jacob and Stephan W Schill, 'Fair and Equitable Treatment: Content, Practice, Method' in Marc Bungenberg and others (eds), International Investment Law: A Handbook (Hart 2015) paras 143-44; Continental Casualty(n 16) para 258.

42 Newcombe (n 1 1) 7 .

43 Regarding the governance function of investment treaty arbitration, see eg Benedict Kingsbury and Stephan W Schill, 'Investor-State Arbitration as Governance: Fair and Equitable Treatment, Proportionality and the Emerging Global Administrative Law' in Albert Jan van den Berg (ed), 50 Years of the New York Convention (Kluwer Law International 2009) 5, 5-6, 23-26; Ortino (n 41) 443-46. 
The concern is that the investment regime, as its least reflective, tends to operate with a default bias against change in the regulatory system of the host state which is fundamentally misaligned with the dynamic and unpredictable policy challenges that states face. ${ }^{44}$ That said, many of the more recent arbitral interpretations and treaty drafting innovations analysed in the following parts suggest that the regime is becoming more sensitive to the need of accommodating legitimate regulatory change, consistent with the broader thesis that the regime is evolving towards a more complicated and balanced goal of sustainable development. ${ }^{45}$

\section{FET: Distinguishing Changes in the Meaning of the Norm and Managing Host State Regulatory Change by Applying the Norm}

\subsection{Meaning of the Norm: Shifting Views Regarding the Stability Element of FET}

One of the most controversial aspects of the FET standard concerns the degree to which it imposes a requirement of stability in the legal and regulatory system of the host state. ${ }^{46}$ As the FET standard is notoriously fact specific, ${ }^{47}$ much of what is at stake in this debate concerns questions of application, or determining what the standard requires in particular circumstances, an issue which will be considered below. Nevertheless, at the level of interpretation, or the meaning in general of the standard, there is a notable shift under-

44 For criticism along these lines see David Schneiderman, Constitutionalizing Economic Globalization: Investment Rules and Democracy's Promise (CUP 2008) 8, 37, 236; Gus Van Harten, 'Investment Rules and the Denial of Change' (2010) 6o UTLJ 893; Gus Van Harten, 'Foreign Investor Protection and Climate Action: A New Price Tag for Urgent Policies' Osgoode Legal Studies Research Paper No 21/2016 (2016) <http://papers.ssrn.com/sol3/ papers.cfm?abstract_id=2697555> accessed 11 September 2017; Lise Johnson and Oleksandr Volkov, 'State Liability for Regulatory Change: How International Investment Rules Are Overriding Domestic Law' (2014) 5(1) ITN 3.

45 For argument that the telos of investment treaties is shifting in this direction, based on recent treaty drafting trends and an evolutionary interpretation of earlier treaty preambles see Federico Ortino, 'Investment Treaties, Sustainable Development and Reasonableness Review: A Case Against Strict Proportionality Balancing' (2017) 30 LJIL 71, 77-83.

46 For an illuminating analysis of this aspect of the FET standard see Hirsch (n 1); see also Richard C Chen, 'A Contractual Approach to Investor-State Regulatory Disputes' (2015) 40 YJIL 295, 313-335 (outlining potential ways to reconceptualise the stability aspect of the FET standard in light of contract law approaches to changed circumstances and risk allocation).

See above $\mathrm{n} 16$. 
way regarding the stability element of the FET standard which is occurring both through more balanced arbitral interpretations and treaty-drafting innovations. ${ }^{48}$ While investment treaties have until recently not further defined the meaning of the terms 'fair and equitable', one element of a number of early arbitral interpretations of the standard was that they saw it as 'inseparable from stability' in the host state's regulatory system, ${ }^{49}$ and suggested that investors could have legitimate expectations arising from the general state of regulation, at the time of investing, in the absence of specific assurances or a stabilization clause..$^{50}$ Among the most striking examples are statements of the Tecmed and Metalclad tribunals which suggested than an investor has the

48 For a similar reading of a shift in arbitral interpretations see Ursula Kriebaum, 'FET and Expropriation in the (Invisible) EU Model BIT' (2014) 15(3-4) JWIT 454, 471. Another aspect of the FET standard which has seen an active dialogue between states as treaty parties and tribunals concerns the norm's relationship with the customary international minimum standard. This example is not treated in detail by this article because it is already well-known in the literature. In short, while the NAFTA treaty parties tied the FET standard to the customary minimum standard through their 2001 authoritative interpretation (above $\mathrm{n} 24$ ) - a move which has since been emulated by other states in drafting treaties - the effectiveness of this technique in curtailing the scope of FET is limited because many tribunals have taken the view that the customary minimum standard has itself evolved. A particularly bold example of this view is the Merrill tribunal, which held FET had become custom and that the broader modern customary minimum standard 'protects against all such acts or behaviour that might infringe a sense of fairness, equity and reasonableness', see Merrill \& Ring (n 16) paras 205-13. In contrast, other tribunals have taken the view that while the customary minimum standard is being applied to a wider range of situations than was historically the case 'the required severity of the conduct' must be maintained, see Cargill, Inc v Mexico, ICSID Case No ARB(AF)/05/Z, Award (18 September 2009) para 284; Glamis Gold Ltd $v$ United States of America, UNCITRAL (NAFTA), Award (8 June 2009) paras 612-16. As others have suggested, the more expansive arbitral interpretations of the customary minimum standard are an example of arbitrators simply moving 'the goal post' in response to this treaty-drafting technique, without sufficiently demonstrating the claimed evolution in custom, see Patrick Dumberry, The Fair and Equitable Treatment Standard: A Guide to NAFTA Case Law on Article 1105 (Kluwer Law International 2013) 107-8; Stephan W Schill, The Multilateralization of International Investment Law (CUP 2009) 274-75.

49 CMS Gas Transmission Co v Argentina, ICSID Case No ARB/o1/8, Award (12 May 2005) paras $276-77$.

50 Occidental Exploration and Production Company v Ecuador, LCIA Case No 3467, UNCITRAL, Final Award (1 July 2004) paras 183, 185; Enron Corp and Ponderosa Assets, LP $v$ Argentina, ICSID Case No ARB/01/3, Award (22 May 2007) paras 260-66; Sempra Energy International $v$ Argentina, ICSID Case No ARB/02/16, Award (28 September 2007) paras 298, 300, 303; Frontier Petroleum Services Ltd v Czech Republic, UNCITRAL, Final Award (12 November 2010) para 285 . 
right to know, before investing, the totality of the applicable regulatory system in order 'to be able to plan its investment'. 51

In contrast, a key idea which animates a host of recent arbitral interpretations of the FET standard is that regulatory change is generally permissible, subject only to restrictions where specific assurances were given to an investor. ${ }^{52}$ These more recent awards have emphasised that the FET standard cannot be interpreted as equivalent to a stabilization clause, and host states retain the ability to adjust regulation to changing economic and social conditions. ${ }^{53} \mathrm{~A}$ key part of this interpretive shift has been to establish that the FET standard requires assessing the reasonableness of the investor's expectations within the totality of the 'political, socioeconomic, cultural and historical conditions pre-

51 Tecnicas Medioambientales Tecmed SA v Mexico, ICSID Case No ARB(AF)/oo/2, Award (29 May 2003) para 154; Metalclad Corp v Mexico, ICSID Case No ARB(AF)/97/1, Award (30 August 2000) para 76 ('all relevant legal requirements for the purpose of initiating, completing and successfully operating investments made, or intended to be made, under the Agreement should be capable of being readily known to all affected investors of another Party').

52 William Ralph Clayton, William Richard Clayton, Douglas Clayton, Daniel Clayton and Bilcon of Delaware, Inc v Canada, PCA Case No 2009-04, UNCITRAL, Award on Jurisdiction and Liability (17 March 2015) para 572; Parkerings-Compagniet AS v Lithuania, ICSID Case No ARB/05/8, Award (11 September 2007) paras 330-33, 338; Saluka Investments BV (The Netherlands) v Czech Republic, UNCITRAL, Partial Award (17 March 2006) paras 304-6; Copper Mesa Mining Corporation v Ecuador, PCA Case No 2012-2, UNCITRAL, Award (15 March 2016) paras 6.61-6.62; Toto Costruzioni Generali SPA v Lebanon, ICSID Case No ARB/07/12, Award (7 June 2012) para 244; Blusun SA, Jean-Pierre Lecorcier and Michael Stein v Italy, ICSID Case No ARB/14/3, Award (27 December 2016) paras 319(4)-(5), $367-74$.

53 Urbaser SA and Consorcio de Aguas Bilbao Bizkaia, Bilbao Biskaia Ur Partzuergoa $v$ Argentina, ICSID Case No ARB/07/26, Award (8 December 2016) paras 607, 628; Philip Morris v Uruguay (n 27) paras 422, 426; El Paso (n 1) paras 350, 352, 367-68; EDF (services) Ltd v Romania, ICSID Case No ARB/05/13, Award (8 October 2009) paras 217-19; AES Summit Generation Ltd and AES-Tisza Erömü Kft v Hungary, ICSID Case No ARB/07/22, Award (23 September 2010) para 9.3.29; Perenco Ecuador Ltd v Ecuador, ICSID Case No ARB/08/6, Decision on Remaining Issues of Jurisdiction and on Liability (12 September 2014) para 586; Ioan Micula et al v Romania, ICSID Case No ARB/05/20, Award (11 December 2013) paras 529, 666, 673; Electrabel $S A v$ Hungary, ICSID Case No ARB/07/19, Decision on Jurisdiction, Applicable Law and Liability (30 November 2012) paras 7.77-7.79. For recognition of this point with qualification see Total (n 1) paras 115-23; Impregilo SpA v Argentina, ICSID Case No ARB/07/17, Award (21 June 2011) paras 290-91; Eiser Infrastructure Ltd and Energia Solar Luxembourg Sàrl v Spain, ICSID Case No ARB/13/36, Award (4 May 2017) paras 362-63, 382 . 
vailing in the host State. ${ }^{54}$ This interpretation operates to limit the investor's legitimate expectations in light of the objective circumstances prevailing in the host state. ${ }^{55}$ Clearly, such an approach places great emphasis on the factspecific application of the FET standard by tribunals. ${ }^{56}$ Nevertheless, staying with the issue of interpretation of the content of the FET standard as a general matter, the shift in arbitral views means it is now clear that where circumstances change - for example through the onset of an economic or public health crisis - investors must expect that regulation will be adjusted accordingly. ${ }^{57}$ Furthermore, as the Philip Morris v Uruguay tribunal put it, the FET standard does: 'not preclude governments from enacting novel rules, even if these are in advance of international practice, provided these have some rational basis and are not discriminatory ... [It] does not guarantee that nothing should be done by the host State for the first time.'58 Yet like most arbitral interpretations of the FET standard, the Tribunal left open that some regulatory changes might 'exceed the exercise of the host State's normal regulatory power in pursuance of a public interest' and modify the regulatory framework relied upon when investing 'outside of the acceptable margin of change'.59 Thus, while contemporary interpretations of the FET standard have become much more accommodating of legitimate regulatory change, there is no hiding that it is arbitrators themselves who determine the 'acceptable margin of [regulatory] change'.

54 Duke Energy Electroquil Partners \& Electroquil SA v Ecuador, ICSID Case No ARB/o4/19, Award (18 August 2008) para 339; Saluka (n 52) para 304; Total SA v Argentina (n 1) para 123; Toto v Lebanon (n 52) para 245; Micula (n 53) para 670. See also the Awards in Mamidoil, Urbaser, and Perenco, all discussed below part 3.2.

El Paso (n 1) para 358; Teinver SA, Transportes de Cercanías SA and Autobuses Urbanos del Sur SA v Argentina, ICSID Case No ARB/o9/1, Award (21 July 2017) para 667; For the suggestion that the obligation to provide a reasonable level of legal stability could be separated from the concept of legitimate expectations, so that the former involves a test focused entirely on the state's circumstances, rather than the investor's expectations, see Simon Maynard, 'Legitimate Expectations and the Interpretation of the "Legal Stability Obligation"' (2016) 1 EILAR 99.

$5^{6}$ AES $v$ Hungary ( $\mathrm{n}_{53}$ ) para 9.3.30 ('Therefore, to determine the scope of the stable conditions that a state has to encourage and create is a complex task given that it will always depend on the specific circumstances that surrounds the investor's decision to invest and the measures taken by the state in the public interest').

57 Murphy Exploration \& Production Company - Internationalv Ecuador, PCA, UNCITRAL, Partial Final Award (6 May 2016) para 276; Urbaser (n 53) para 628; Continental Casualty (n 16) para 258.

$58 \quad$ Philip Morris v Uruguay (n 27) para 430.

59 ibid para 423, partially quoting El Paso (n 1) para 402. 
Recent treaty-drafting practices reveal significant efforts by states to curtail the meaning of the FET standard and specifically its stability element. A notable development is the FET provision within the Comprehensive Economic and Trade Agreement between Canada and the European Union (CETA). CETA moves to what is intended as an exhaustive list of the types of conduct which breach the standard - thus reducing the discretion delegated to arbitrators over the meaning of the norm - and excludes any reference, within the proscribed conduct, to stability in the host state's regulatory system. ${ }^{60} \mathrm{~A}$ very similar provision was proposed by the EU within the Transatlantic Trade and Investment Partnership (TTIP) negotiations. ${ }^{61}$ The grounds for liability under the FET standard are instead limited to such high thresholds as treatment which constitutes a 'fundamental breach of due process ... in judicial and administrative proceedings' or 'manifest arbitrariness'. ${ }^{62}$ Yet because these terms are open-ended and evaluative, significant discretion is still delegated to adjudicators with regard to both interpretation, or determining the precise content of such terms, and applying them to specific factual situations. ${ }^{63}$ CETA's FET clause further provides that tribunals may consider, in applying the standard, 'whether a Party made a specific representation to an investor to induce a covered investment, that created a legitimate expectation, and upon which the investor relied in deciding to make or maintain the covered investment, but that the Party subsequently frustrated'. ${ }^{64}$ While this appears to be intended to restate the principle, established in arbitral jurisprudence, that specific assurances are a decisive consideration in relation to the creation of legitimate expectations, and any obligation to provide regulatory stability, more could have been done to clarify this aspect of the norm's content. In particular, something may have been said about the type of conduct from which legitimate expectations can arise - a matter on in which arbitral tribunals have advanced certain views ${ }^{65}$ - including whether such representations must be in writing and

6o CETA (n 23) art 8.10(1)-(2). However, it is not explicitly stated that the types of listed conduct which breach the FET standard are exhaustive, so some doubt remains, see De Brabandere (n 4) 300.

61 European Union, 'Transatlantic Trade and Investment Partnership - Trade in Services, Investment and E-Commerce - Chapter II: Investment' (12 November 2015) art 3(1)-(2) (hereinafter: TTIP Proposal) <http://trade.ec.europa.eu/doclib/docs/2015/november/ tradoc_153955.pdf $>$ accessed 11 September 2017.

62 CETA (n 23) art 8.10(2)(b)(c).

63 Henckels (n 22) 37, 40. See also above text at nn 19-21.

64 CETA (n 23) art 8.10(4).

65 See eg LG\&E Energy Corp et al v Argentina, ICSID Case No ARB/02/1, Decision on Liability (3 October 2006) para 130 (suggesting legitimate expectations of an investor must be 
whether the representations must be made to a specific investor. ${ }^{66}$ States as treaty parties could also further clarify the types of circumstances in which it is permissible for host states to act contrary to legitimate investor expectations once they are established. ${ }^{67} \mathrm{~A}$ more successful example of states' attempts to clarify the meaning of the FET standard, and make it more accommodating of regulatory change, is perhaps CETA's provision that a host state's decision not to issue, renew, or maintain a subsidy does not constitute a breach of investment protection obligations in the absence of specific commitments under a law or contract to the contrary. ${ }^{68}$ The next Part turns to the role of tribunals in applying the FET standard to specific disputes, and demonstrates how this involves adjudicating on the permissible margin of host state regulatory change.

\subsection{Applying the FET Standard: Determining the Permissible Margin of Host State Regulatory Change}

This Part focuses in greater detail on a limited number of recent cases which have foregrounded the issue of how to apply the FET standard in a manner which is sensitive to the host state's interest in being able to adjust regulation to evolving circumstances. A useful starting point is provided by the 2015 award in Mamidoil v Albania, where the Tribunal understood the FET standard as protecting investors from 'inacceptable and inappropriate changes of conditions and circumstances by the State' while recognising 'a State's legitimate interest and right to change conditions reasonably for public policy purposes' ${ }^{69}$ The case concerned an investment in the construction and operation of an oil container terminal at a port and the host state's decision to close the port to petroleum tankers as part of a rezoning aimed at environmental remediation.

'enforceable by law'); Continental Casualty (n 16) para 261 (suggesting the specificity of the alleged undertaking must be considered as 'political statements have the least legal value ... general legislative statements engender reduced expectations' and contractual obligations 'generate as a rule legal rights and therefore expectations of compliance'); Blusun (n 52) paras $367-71$.

$66 \quad$ Kriebaum (n 48) 478; Henckels (n 22) 38.

67 Henckels (n 22) 38-39 (highlighted that CETA only clarifies that such a departure from legitimate expectations would have to be 'manifestly arbitrary' to constitute a FET violation, which still leaves substantial discretion to arbitrators).

68 CETA (n 23) art 8.9(3); see also art 8.9(2) concerning the modification of host state laws generally. The EU's TTIP Proposal (n 61) contained the same language regarding the removal of subsidies and was more explicit regarding the permissibility of regulatory change in general, see arts 2.2, 2.3. Compare TPP (n 23) art 9.6(4)-(5).

69 Mamidoil Jetoil Greek Petroleum Products Societe SA v Albania, ICSID Case No ARB/11/24, Award (30 March 2015) paras 634, 703. See also paras 613-18. 
In finding that the zoning change was as a legitimate exercise of sovereign power and 'did not lead to unreasonable instability', ${ }^{70}$ the Tribunal emphasised that Albania was a country in transition from a communist regime, which had a pressing need to modernise its infrastructure with limited resources. ${ }^{71}$ Thus, investors could not expect the 'same results of stability as in as in Great Britain, USA or Japan. ${ }^{72}$ Furthermore, no specific assurances had been given to the investor regarding the use of the port, ${ }^{73}$ and the measures were of a general nature, affecting all companies operating at the port. ${ }^{74}$ Albania had in fact pursued its modernisation process 'in a gradual way', and the potential policy changes were first communicated to the investor at a point when it still retained significant flexibility, not having made the bulk of its investment. ${ }^{75}$ In short, the Award is a prime example of the manner in which investment arbitrators, by applying the FET standard, adjudicate on the permissible degree of change within the host state's regulatory system.

The role of investment arbitrators in adjudicating on host state regulatory change is further thrown into relief by the recent Urbaser $v$ Argentina award. Like numerous other investment arbitrations, this case concerned emergency measures adopted by Argentina in response to its economic crisis which affected a concession for the supply of public utilities, specifically water and sewage services in Buenos Aires. A key contribution of the Urbaser award is to embed the parties' contractual relationship within the wider legal and social context. The Tribunal emphasised that while an 'investor's expectations ... are usually measured on the basis of the contractual commitments ... these contractual rights should not be considered in isolation, ${ }^{76}$ and must be understood within a wider 'legal environment also covering core interests of the host State, as protected by sources of law prevailing over the Contract, based on international or on constitutional law'. ${ }^{77}$ Specifically, Argentina's obligation to guarantee the right to water to millions of its constituents was 'the framework within which' the investor's expectations had to be assessed. ${ }^{78}$ Thus, the Tribunal held that the requirement under the FET standard to treat the investor with transparency could not mean that the investor would be protected from 'any change of

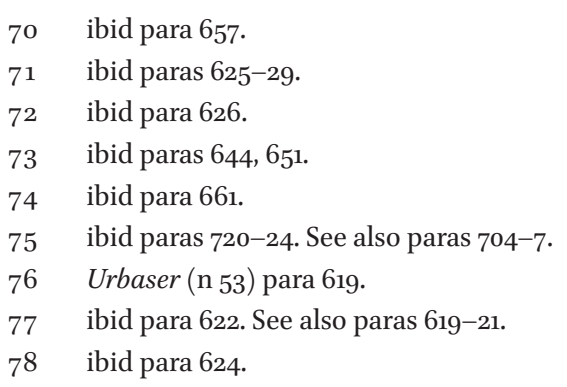


the circumstances in the lifetime of the investment ... [which] had not been transparent from the outset. ${ }^{79}$ Instead, the investor had to be 'aware of the State's commitment to deal with situations and problems' which may emerge over time 'and were impossible to anticipate. ${ }^{80}$ Nevertheless, the FET standard required that the basic expectations of the investor in respect of the fate of its investment ... [were] taken care of by the host State when reacting to unforeseen circumstances'.81 Applying this standard, the Tribunal found a breach of the FET standard not because of Argentina's adoption of emergency measures, which were viewed as justified, ${ }^{82}$ but because of its refusal to seriously engage with the investor in renegotiating the concession, in light of the changed circumstances. ${ }^{83}$ Again, it is the international tribunal, through its fact-intensive application of the FET standard, which has ultimately determined the permissible degree of change within the host state's regulatory system.

A third set of cases which squarely raise the question of the 'acceptable margin of change' 84 within the host state's regulatory system are those disputes arising out of Ecuador's windfall profits tax enacted in the context of an unexpected rise in oil prices. By way of context, the participation contracts between Ecuador and foreign oil companies relevant to these disputes did not contain stabilization clauses but provisions which required the parties to renegotiate the contract, in order to restore the underlying economic bargain, in the event of certain 'trigger' events. ${ }^{85}$ Thus, both the Murphy and Perenco tribunals quickly concluded that the oil companies could not 'reasonably expect that the contracts would be completely immunised from future legislative or other measures' ${ }^{\prime 86}$ given the state's interest as sovereign over its natural resources in a context of 'exceptional price rises. ${ }^{87}$ Both of these Tribunals held that Ecuador's

\footnotetext{
79 ibid para 628 .

80 ibid.

81 ibid. See also paras $631-32$.

82 ibid paras $716-38$.

83 ibid para 845 . See generally paras $813-45$. Note, however, that this treaty breach was held not to be the cause of the Claimant's loss, ibid paras 846-47. Other awards concerning Argentina's emergency measures have also held that it was Argentina's failure to seriously engage with the investor to readjust the contractual framework, in light of unforeseen circumstances, which constituted a violation of the FET standard, see eg Impregilo ( $\mathrm{n}_{53}$ ) paras $325^{-31 .}$

$84 \quad$ El Paso $\left(\mathrm{n}_{1}\right)$ para 402.

85 Perenco v Ecuador (n 53) para 562; Murphyv Ecuador (n 57) para 279; Occidental Petroleum Corporation and Occidental Exploration and Production Company v Ecuador, ICSID Case No ARB/o6/11, Award and Dissenting Opinion of Arbitrator Stern (5 October 2012) para 12.

86 Perenco $v$ Ecuador (n 53) paras 578, 588, 591.

$87 \quad$ Murphyv Ecuador $\left(\mathrm{n}_{57}\right)$ para 276.
} 
measure, as initially enacted at $50 \%$ of exceptional revenues, did not breach the FET standard. ${ }^{88}$ Instead, it was Ecuador's increasing of the state's share of exceptional revenues to $99 \%$, combined with a series of coercive measures designed to force the oil companies to accept a shift from participation to service contracts, which violated their legitimate expectations that any contractual rebalancing would occur through a mutually agreed process. ${ }^{89}$ Like the Urbaser award, these tribunals embedded the parties' contractual relationship within the relevant social, political, and economic context. ${ }^{90}$ Also similarly to Urbaser, it was the host state's failure to seriously negotiate with the investor to rebalance the contract, in the context of unforeseen circumstances, which constituted the FET breach, rather than the decision to respond to changed circumstances per se, which was viewed as a legitimate regulatory determination. Thus, in assessing treaty-based liability, arbitrators arrived at a reconciliation of the competing interests which resembles the compromise contained in some types of adaptation clauses within investor-state contracts, namely that where the economic equilibrium of the contract is affected there is an obligation to negotiate a rebalancing of the contract or to pay compensation. ${ }^{91}$

88 ibid para 280 ; Perenco $v$ Ecuador ( $\mathrm{n}_{53}$ ) para 593 (noting at paras 592-94 that it was open to the Claimant to attempt to renegotiate the contract); Burlington Resources Inc $v$ Ecuador, ICSID Case No ARB/08/5, Decision on Liability (14 December 2012), did not address the consistency of Ecuador's measures with the FET standard because the Tribunal had earlier found it lacked jurisdiction over this part of the claim, see para 85 .

89 Murphyv Ecuador (n 57) paras 282, 292-93; Perenco $v$ Ecuador (n 53) paras 6o6-7.

90 The same cannot be said for the reasoning of the majority in Occidental $v$ Ecuador, Award (n 85) paras 523-27, which held that Ecuador's initial measure, enacted at 50\% of exceptional revenues, constituted a breach of the FET standard, offering little reasoning beyond the fact that it constituted a breach of contract. Contrast the Dissenting Opinion of Arbitrator Stern who noted the general ability of states to alter their tax regimes and held that Ecuador's measures did not trigger the contractual renegotiation clause, let alone rise to the level of a treaty breach, ibid, Dissent, paras 9-13.

91 See Lorenzo Cotula, 'Reconciling Regulatory Stability and Evolution of Environmental Standards in Investment Contracts: Towards a Rethink of Stabilization Clauses' (2008) 1 JWELB 158, 161, 165, 167; For background on the operation of contractual stabilization and adaptation clauses see AFM Maniruzzaman, 'The Pursuit of Stability in International Energy Investment Contracts: A Critical Appraisal of the Emerging Trends' (2008) 1JWELB 121, 122-34; Piero Bernardini, 'Stabilization and Adaptation in Oil and Gas Investments' (2008) 1 JWELB 98, 100-10; Peter D Cameron, International Energy Investment Law: The Pursuit of Stability (OUP 2010) 68-94; Klaus Peter Berger, 'Renegotiation and Adaptation of International Investment Contracts: The Role of Contract Drafters and Arbitrators' (2003) 36 Vanderbilt J Transnatl L 1347, 1357-80. Suggestions for rethinking the role of stabilization or adaptation clauses given investment treaty law's acceptance of certain types 
The key point is that in all of the above examples it is investment arbitrators, by applying the FET standard, who ultimately determine the permissible margin of regulatory change open to the host state in responding to unforeseen circumstances.

\section{Change and the Protection Against Indirect Expropriation}

\subsection{Changes in the Meaning of the Norm}

This Part considers the interpretive dialogue between treaty parties and tribunals which has contributed to the evolution of the meaning of the protection against indirect expropriation over the last decade or so. The starting point here is to note that prior to the last ten years, most investment treaties contained a guarantee against direct and indirect expropriations without adding further detail. ${ }^{92}$ Accordingly, arbitral tribunals were left substantial discretion in giving meaning to the concept of indirect expropriation. At the level of contributions by arbitral tribunals, a significant development in the meaning of the indirect expropriation standard has been the recognition, and articulation in different formulations, of a police powers doctrine. As the Philip Morris $v$ Uruguay Tribunal observed, while a police powers doctrine was recognised in customary international law prior to the rise of investment treaty arbitration, the principle:

did not find immediate recognition in investment treaty decisions. But a consistent trend in favor of differentiating the exercise of police powers from indirect expropriation emerged after 2000. During this latter period, a range of investment decisions have contributed to develop the scope, content and conditions of the State's police powers doctrine ${ }^{93}$

of legitimate regulatory change, and the need to adapt regulation in response to environmental and other policy problems are provided in Cotula (n 91); Antoine Martin, 'Stability in Contemporary Investment Law: Reconsidering the Role and Shape of Contractual Commitments in Light of Recent Trends' (2013) 10 Manchester JIEL 38. Regarding the normative questions raised by this area of practice, see especially Tienhaara (n 1) 159-67.

92 Jonathan Bonnitcha, Substantive Protection Under Investment Treaties: A Legal and Economic Analysis (CUP 2014) 230; UNCTAD, 'Taking Stock' (n 22) 9 (reporting from a sample of 862 BITs that of those treaties signed between $1962-2011$ only $4 \%$ contained criteria further defining the meaning of indirect expropriation). 
In understanding this apparent shift in arbitral interpretations it should be noted that there are relatively few investment treaty tribunals which have refused to allow any form of police powers exception by holding that a measure's purpose is irrelevant to whether it constitutes an indirect expropriation. ${ }^{94}$ One stark example is provided by the Metalclad award which dismissed the relevance of the 'motivation or intent' behind a provincial decree, adopted on purportedly ecological grounds, which was held to constitute an indirect expropriation. ${ }^{95}$ While other early NAFTA awards had noted the existence of a police powers exception, ${ }^{96}$ in retrospect a seminal contribution seems to have been made by an oft-cited passage of the Methanex award that:

as a matter of general international law, a non-discriminatory regulation for a public purpose, which is enacted in accordance with due process and, which affects, inter alios, a foreign investor or investment is not deemed expropriatory and compensable unless specific commitments had been given by the regulating government ${ }^{97}$

94 Compañia de Aguas del Aconquija SA and Vivendi Universalv Argentina, ICSID Case No ARB/97/3, Award (21 August 2007) paras 7.5.20-7.5.21; Siemens AG v Argentina, ICSID Case No ARB/02/8, Award (6 February 2007) para 270; Marion Unglaube and Reinhard Unglaube $v$ Costa Rica, ICSID Case Nos ARB/08/1 and ARB/og/20, Award (16 May 2012) paras 213-18. See also Pope \& Talbot Inc $v$ Canada, UNCITRAL (NAFTA), Interim Award (26 June 2000) paras 96, 99 .

95 Metalclad (n 51) paras 109-11. The Tribunal's determination that Mexico's earlier denial of a permit constituted an indirect expropriation also placed little weight on the environmental reasons said to be behind the decision, ibid paras 92, 106-7.

96 SD Myers, Inc v Canada, UNCITRAL (NAFTA), Partial Award (13 November 2000) paras 281-82; Marvin Feldman v Mexico, ICSID Case No ARB(AF)/99/1, Award (16 December 2002) paras 105-6, 112.

97 Methanex Corporation v USA, UNCITRAL (NAFTA), Final Award (3 August 2005) pt IV ch D para 7. In reading this statement it should be noted that there is an important question of how the reference to 'public purpose', as a condition of a police powers doctrine which provides a justification for non-compensation, interacts with the criterion of public purpose that is a condition of a lawful expropriation under investment treaties and customary international law. One answer to this apparent tension is that the police powers exception concerns a much narrower concept of public purpose which does not cover all forms of domestic regulation. Specifically, the kinds of public purposes that may justify non-compensation are essentially public order and morality, protection of the public against human health or environmental risks, and taxation, see generally Newcombe (n 1) 26-43. For a contrary argument that the Methanex award did not have a substantial impact on subsequent arbitral decision-making, see Kyla Tienhaara and Todd Tucker, 'Regulating Foreign Investment: Methanex Revisited' in Chin Leng Lim (ed), 
The existence of such a police powers exception has since been affirmed by numerous tribunals as a matter of legal principle, whether or not they have found that an expropriation occurred on the facts of the case. ${ }^{98}$ However, there are substantial differences within the formulations. In contrast to the Methanex formulation, cited above, numerous tribunals have imposed the condition that any regulatory measure must be proportionate to the public interest being pursued, having regard to the impact on protected investor interests. ${ }^{99}$ This is notable because the introduction of proportionality balancing into the indirect expropriation norm has occurred through arbitral interpretations of the norm, drawing on European human rights jurisprudence. ${ }^{100}$

The evolution of the indirect expropriation standard is, however, only partly a story of shifting tribunal interpretations. A landmark development in this area was the introduction within the 2004 Model BITs of the United States and Canada of remarkably similar Annexes which provided a non-exhaustive list of factors to be considered in determining whether an indirect expropriation had occurred, and a general exclusion for non-discriminatory regulatory measures. ${ }^{101}$ These treaty-drafting techniques have been emulated in numerous investment treaties over the last decade, ${ }^{102}$ and further developed in some of the newest instruments considered below. Notably, such treaty-based

Alternative Visions of the International Law on Foreign Investment: Essays in Honour of Muthucumaraswamy Sornarajah (CUP 2016) 255.

98 Saluka (n $\left.5_{2}\right)$ para 262; Chemtura (n 16) para 266; Copper Mesa (n $\left.5^{2}\right)$ para 6.60; Burlington (n 85) para 506; WNC Factoring Ltd v Czech Republic, PCA Case No 2014-34, UNCITRAL, Award (22 February 2017) para 40o(e); Continental Casualty (n 16) paras 276, 278.

99 Tecmed (n 51) paras 121-22; Philip Morris v Uruguay (n 27) paras 305-7; Azurix Corp v Argentina, ICSID Case No ARB/o1/12, Award (14July 2006) paras 311-12; El Paso (n 1) paras 233-34; $L G \& E$ (n 65) para 195.

100 Tecmed (n 51$)$ para 122. For consideration of the appropriateness of this analogy, see eg José E Alvarez, 'The Use (and Misuse) of European Human Rights Law in InvestorState Dispute Settlement' in Franco Ferrari (ed), The Impact of EU Law on International Commercial Arbitration (Juris 2017) 519.

101 US Model BIT (2004) Annex B <www.state.gov/documents/organization/117601.pdf>; Canada Model FIPA (2004) Annex B.13(1) <www.italaw.com/documents/Canadian2004FIPA-model-en.pdf $>$ all accessed 11 September 2017 .

102 See eg 2012 US Model BIT (n 29) Annex B(4); Canada-Peru FTA (n 29) Annex 8.12.1; Agreement Establishing the ASEAN-Australia-New Zealand Free Trade Area (signed 27 February 2009, entered into force 1 January 2010) [2010] ATS 1, ch 11, Annex, (3)-(4). See also Tienhaara and Tucker (n 97) 279-80 (providing empirical evidence of the growing proportion of treaties with 'safeguards' clarifying the meaning of expropriation); UNCTAD (n 22) 9 (noting some $35 \%$ of the investment treaties sampled between 20122015 contain criteria clarifying the meaning of indirect expropriation, and listing treaties 
innovations came just before the rise of the police powers doctrine in arbitral jurisprudence, captured most starkly in the Methanex award, and in the wake of the Metalclad case which had endorsed a particularly broad definition of indirect expropriation that had been subject to criticism. ${ }^{103}$ Thus, one plausible reading of these developments is that later arbitral tribunals have been influenced by states' attempts to refine the meaning of the indirect expropriation norm, even when interpreting older investment treaties that do not contain additional provisions clarifying the meaning of this standard. ${ }^{104}$

Turning in greater detail to the treaty-drafting innovations aimed at controlling the meaning of the indirect expropriation standard I will use as a focus the Annex addressing expropriation within CETA, ${ }^{105}$ which was included in a largely identical form in the EU's proposed TTIP text. ${ }^{106}$ The first notable innovation is that CETA's Annex seeks to define when a measure has 'an effect equivalent to direct expropriation', a matter left open by earlier treaties, by introducing a threshold that the measure 'substantially deprives the investor of the fundamental attributes of property in its investment, including the right to use, enjoy and dispose of its investment, without formal transfer of

from 2011-2015, including regarding whether they define indirect expropriation, in Annex Tables 1-5).

103 In the set-aside proceedings in the Canadian courts Justice Tysoe, although not setting aside the Award in this respect, noted the Metalclad tribunal's definition of expropriation was 'extremely broad' and could 'include a legitimate rezoning of property', see United Mexican States $v$ Metalclad [2001] BCSC 664 (Decision of 2 May 2001) para 99.

104 Federico Ortino, 'Defining Indirect Expropriation:The Transatlantic Trade and Investment Partnership Approach and the (Elusive) Search for "Greater Certainty"' (2016) 43 LIEI 351, 354 (text at fn 11); Kriebaum (n 48) 465. Consider in this regard Philip Morris v Uruguay (n 27) paras 300-1 (citing such treaty-drafting developments as support for the existence of a police powers doctrine in a treaty that did not explicitly recognise such an exception). It should be noted that other factors, beyond states' adoption of expropriation annexes, may also help explain certain tribunal interpretations. For example, the Methanex formulation of the police powers doctrine closely follows the formulation advanced in the United States' memorial, see Amended Statement of Defense of Respondent (5 December 2003) paras 409-411 <www.state.gov/documents/organization/27063.pdf> accessed 29 May 2017. Furthermore, this aspect of the Methanex award can arguably be seen as, in part, responding to the unusual public attention the case had attracted, see Tienhaara and Tucker (n 97) 267.

105 CETA (n 23) Annex 8-A.

106 EU TTIP Proposal (n 61) Annex I. In contrast, the expropriation annex in the TPP contains fewer innovations and largely resembles the approach introduced by the 2004 US Model BIT (n 101), see TPP (n 23) Annex 9-B. 
title or outright seizure'. ${ }^{107}$ While the reference to a 'substantial deprivation' is a codification of established arbitral interpretations, ${ }^{108}$ the requirement that it relates to 'the fundamental attributes of property ... including the right to use, enjoy and dispose' of an investment is an intervention which seeks to push the indirect expropriation norm in the direction of those awards which have emphasised the need for a measure to substantially deprive the investor of its proprietary rights, such as the control or use of an investment, rather than merely causing a reduction in the value of the investment. ${ }^{109}$ However, CETA leaves unresolved whether other 'fundamental attributes of property' may exist - given the use of 'including' - and whether 'a right to the "value"' of an investment could be interpreted as such an additional attribute. ${ }^{110}$ Even if the latter interpretation is not adopted, a question remains of whether a reduction in the value of an investment may at some (extreme) point be held to constitute a 'substantial deprivation' of the right to 'use, enjoy and dispose of' an investment. ${ }^{111}$ Again, what this suggests is that significant discretion is left for future arbitral tribunals both in interpreting the precise content of such 'new style' investment treaty provisions and in applying them to specific disputes.

The second paragraph of CETA's expropriation Annex slightly extends a list of factors first included in the 2004 US Model BIT which must be considered in determining whether a measure constitutes an indirect expropriation. These factors are drawn from Penn Central, the leading US domestic case on

\footnotetext{
107 CETA (n 23) Annex 8-A, para 1(b).

108 See eg Chemtura (n 16) para 242; El Paso (n 1) para 255; Sempra (n 50) para 284; Pope \& Talbot (n 94) para 102; CMS (n 49) paras 262-63.
}

109 See especially El Paso (n 1) paras $245^{-56}$ (reviewing prior arbitral jurisprudence to make this point); Pope \& Talbot (n 94) paras 100-2; Sempra (n 50) paras 284-85; LG\&E (n 65) paras 191, 198; Biwater Gauff (Tanzania) Ltdv Tanzania, ICSID Case No ARB/o5/22, Award (24 July 2008) paras 463-64 (emphasizing the distinction between a substantial interference with rights and economic loss); Chemtura (n 16) paras 244-49 (noting this 'legal controversy' over what is required for a substantial deprivation but not settling it); Bonnitcha (n 92) 247-54 (classifying awards based on whether they focus on a measure's effect on the value of an investment or on the investor's proprietary rights).

110 Ortino (n 104) 357-58.

111 ibid 358. Some tribunals have endorsed the proposition that a measure which completely destroys the value of an investment would constitute an indirect expropriation, see eg Sempra (n 50) para 285; Tecmed (n 51) para 115; Venezuela Holdings BV et al $v$ Venezuela, ICSID Case No ARB/07/27, Award (9 October 2014) para 286. See also Rudolf Dolzer and Christoph Schreuer, Principles of International Investment Law (2nd edn, OUP 2012) 118 (arguing indirect expropriation extends to instances where an investor is substantially deprived of the value of an investment because the relevant criteria include 'economic use and benefit' of an investment, not just control). 
regulatory takings, ${ }^{112}$ and were utilised by US negotiators as a result of a 2002 instruction from the US congress to ensure that investment treaty protections, and specifically provisions on expropriation, did not exceed the protections provided by US law. ${ }^{113}$ The innovations introduced by CETA in this area (and the EU's TTIP Proposal) are relatively minor when read against the 2004 US Model BIT. ${ }^{114}$ The more remarkable point, from the perspective of the evolving meaning of the indirect expropriation norm, is the successful 'exporting' of the Penn Central factors, ${ }^{115}$ a domestic takings rule, into numerous investment treaties in the space of a decade or so. While it can be argued that the Penn Central factors are largely similar to the range of factors international tribunals consider anyway in delimiting compensable takings from legitimate regulation, ${ }^{116}$ their repetition in numerous treaties is an excellent example of a small number of influential states influencing the broader trajectory of international investment norms. ${ }^{117}$

112 Penn Central Transportation Co v New York City, 438 US 104 (1978).

113 For discussion of this background, see Gary H Sampliner, 'Arbitration of Expropriation Cases Under US Investment Treaties - A Threat to Democracy or the Dog That Didn't Bark?' (2003) 18 ICSID Rev-FILJ 1, 35-39; Matthew C Porterfield, 'International Expropriation Rules and Federalism' (2004) 23 Stan Envtl L J 3, 41-43.

114 Compare US Model BIT (2004) Annex B, para 4(a) with CETA (n 23) Annex 8-A, para 2. For example, the instruction in para 2(b) of CETA's Annex 8-A that tribunals must consider the duration of a measure is new but simply codifies a consideration tribunals already emphasise, namely that a deprivation must be permanent rather than temporary to qualify as an expropriation. Paragraph 2(d) of CETA's Annex 8-A states that in considering the character of a measure tribunals must consider the measure's 'object, context and intent', whereas earlier versions of such provisions had simply referred to the character of a measure. This addition appears to reaffirm the existence of a police powers exception because consideration of the 'object, context and intent' of a measure will often be crucial to distinguishing legitimate regulations from compensable takings, even though a lack of intent does not provide a defence against an expropriation claim, see Newcombe (n 1) 25, 41. For argument that the inclusion of intent as a factor is problematic, see Kriebaum (n 48$) 465$.

115 Anthony B Sanders, 'Of All Things Made in America Why Are We Exporting the Penn Central Test' (2010) 30 Northwest J Intl L\& Bus 339.

116 Sampliner (n 113) 11-15; Bonnitcha (n 92) 268.

117 For explanation of why 'path dependency' can develop in investment treaty design, whereby certain drafting choices become entrenched in the investment treaty network, see Wolfgang Alschner, 'Locked in Language: Historical Sociology and the Path Dependency of Investment Treaty Design' in Moshe Hirsch and Andrew Lang (eds) Research Handbook on the Sociology of International Law (Edward Elgar) (forthcoming) <https://papers.ssrn .com/sol3/papers.cfm?abstract_id=2929762 $>$ accessed 11 September 2017. 
The third innovation regarding the meaning of indirect expropriation introduced by the 2004 US and Canadian Model BITs and further developed in the most recent treaties is a provision which with some variations states that: 'except in rare circumstances, non-discriminatory regulatory actions by a Party that are designed and applied to protect legitimate public welfare objectives, such as public health, safety, and the environment, do not constitute indirect expropriations. ${ }^{118}$ A major unresolved ambiguity regarding this type of provision is what constitutes 'rare circumstances'. CETA, and the EU's TTIP proposal, attempt to clarify what constitutes 'rare circumstances' by referring in the singular to 'the rare circumstance when the impact of a measure or series of measures is so severe in light of its purpose that it appears manifestly excessive.'119 Compared to earlier treaties which did not define 'rare circumstances' this provision reduces the interpretive discretion of future arbitral tribunals. However, the content of this provision could be made clearer by specifying a methodology which is to be utilised by tribunals in undertaking the balancing exercise the provision mandates between the impact of a measure on protected investor interests and the public policy purpose pursued. ${ }^{120}$ Furthermore, even if a specific methodology, such as least restrictive means testing, were specified, including such a balancing test plainly delegates substantial discretion to the arbitrators charged with applying it. ${ }^{121}$ There is an important contrast here with a minority of investment treaties which have sought to do away with a balancing exercise - and the significant discretion at the level of application it necessarily delegates to arbitrators - by removing the qualification based on 'rare circumstances' entirely. ${ }^{122}$

\section{US Model BIT (n 101) Annex B, para 4(b).}

119 CETA (n 23) Annex 8-A, para 3; EU TTIP Proposal (n 61) Annex I, para 3. The 2004 Canada Model FIPA ( $\mathrm{n}$ 101) was less successful in reducing this ambiguity because in defining 'rare circumstances' it referred non-exhaustively to 'such as when a measure or series of measures are so severe in the light of their purpose that they cannot be reasonably viewed as having been adopted and applied in good faith', see ibid Annex B.13(1) para (c).

120 Henckels (n 22) 43; Ortino (n 104) 362-3.

121 For an example of a treaty provision from outside the investment context which explicitly states that the applicable balancing technique is least restrictive means testing see Agreement on the Application of Sanitary and Phytosanitary Measures, Marrakesh Agreement Establishing the World Trade Organisation, Annex 1A (opened for signature 15 April 1994, entered into force 1 January 1995) 1867 UNTS 493, art 5.6 and fn 3.

122 Such treaties provide, without qualification, that non-discriminatory regulatory measures designed and applied to achieve legitimate public welfare objectives do not constitute an expropriation, see eg ASEAN-Australia-New Zealand FTA (n 102) ch 11, Annex, 
This Part has shown that the content of the protection against indirect expropriation has undergone significant evolutions over the last decade through contributions both by tribunals as treaty interpreters and states as treaty drafters. The next Part moves back to the realm of application, a process dominated by tribunals, to demonstrate that in applying the indirect expropriation standard in concrete disputes, arbitrators frequently adjudicate on the permissible margin of host state regulatory change.

\subsection{Managing Host State Regulatory Change by Applying the Indirect Expropriation Standard}

My concern in this Part is with how tribunals have applied the indirect expropriation standard to particular disputes and in doing so have determined the permissible degree of host state regulatory change. As noted above, only a few arbitral tribunals have applied a true 'sole effects' test which rejects the idea that a measure's purpose is ever relevant to whether it constitutes an indirect expropriation. Thus, accordingly to most arbitral awards, and the widespread treaty-drafting innovations outlined above, some form of police powers exception exists, whereby, although under different conditions, some forms of nondiscriminatory regulatory conduct may be held not to constitute an indirect expropriation. The idea of property which animates this view is a qualified and social one, ${ }^{123}$ where investments are 'constituted, bounded and periodically redefined by regulation.' ${ }^{24}$ A good example of this view being applied is the Methanex case, where the Claimant challenged California's ban on a gasoline additive. As part of its finding that the measure constituted a valid exercise of the authorities' police powers, the Tribunal noted that Methanex had:

entered a political economy in which it was widely known, if not notorious, that governmental environmental and health protection institutions at the federal and state level, operating under the vigilant eyes of the media, interested corporations, non-governmental organizations and a politically active electorate, continuously monitored the use and impact of chemical compounds and commonly prohibited or restricted the use

para 4; India Model BIT (2015) art 5.5 <www.mygov.in/sites/default/files/master_image/ Model\%2oText\%2ofor\%2othe\%2oIndian\%2oBilateral\%2oInvestment\%2oTreaty.pdf> accessed 11 September 2017.

123 Newcombe (n 1 ) 27.

124 Thomas WWälde and Abba Kolo, 'Environmental Regulation, Investment Protection and "Regulatory Taking” in International Law' (2001) 50 ICLQ 811, 823. 
of some of those compounds for environmental and/or health reasons ... the very market ... was the result of precisely this regulatory process ${ }^{125}$

The key point is that in applying the indirect expropriation standard to the facts of the case, the international tribunal has itself determined the permissible balance between the investor's interest in regulatory stability and the host state's interest in adjusting regulation to address newly appreciated environmental and public health risks.

The idea that legitimate regulatory changes can damage the commercial viability of an investment without constituting an indirect expropriation is also central to the reasoning in Feldman $v$ Mexico, ${ }^{126}$ which involved a challenge by the Claimant to measures which prevented his company from accessing a rebate for the export of 'grey market' cigarettes. In rejecting the expropriation claim, the Tribunal noted that:

not all government regulatory activity that makes it difficult or impossible for an investor to carry out a particular business, change in the law or change in the application of existing laws that makes it uneconomical to continue a particular business, is an expropriation ... Governments, in their exercise of regulatory power, frequently change their laws and regulations in response to changing economic circumstances or changing political, economic or social considerations. Those changes may well make certain activities less profitable or even uneconomic to continue. ${ }^{127}$

The Tribunal emphasised that Mexico was not required to permit 'grey market' cigarette exports; nor did the investor have a 'right' to make such exports under Mexican law; and Mexico's measure had a rational public policy basis. ${ }^{128}$ Again, in applying the indirect expropriation standard to the facts the Tribunal has itself drawn the line between legitimate regulatory changes which make an investor's business difficult or uneconomic, and changes which constitute a compensable taking.

Another set of cases which have required arbitrators to determine the permissible margin of regulatory change within the host state are disputes concerning whether taxation changes constitute an indirect expropriation. The basic principle in this area was articulated by the Encana $v$ Ecuador tribunal,

\footnotetext{
125 Methanex (n 140) pt IV, ch D, para 9.

126 Feldman v Mexico (n 96).

127 ibid para 112.

128 ibid paras $111,136$.
} 
which noted that: 'In the absence of a specific commitment from the host State, the foreign investor has neither the right nor any legitimate expectation that the tax regime will not change, perhaps to its disadvantage, during the period of the investment.'129 Applying this principle, the Tribunal noted that while the change in taxation laws had caused the Claimant to suffer financially, it had not 'brought the companies to a standstill or rendered the value to be derived from their activities so marginal or unprofitable as effectively to deprive them of their character as investments.130 Similarly, those tribunals which have considered whether Ecuador's windfall profits tax constituted an indirect expropriation have emphasised that while this tax change clearly caused financial harm to the investors, it did not destroy the underlying investments. ${ }^{131}$ Likewise, tribunals adjudicating on Argentina's measures adopted in the context of its economic crisis, including tax changes, have consistently recognised that while Argentina's measures caused investors financial loss, they did not constitute indirect expropriations given investors were not substantially deprived of the control and use of their investments. ${ }^{132}$ In all of these examples it is international arbitrators, in applying the indirect expropriation standard, who are determining the permissible balance between host states' interest in adjusting regulation to unforeseen circumstances, including in ways that cause financial harm to existing investments, and investors' standard arguments in favour of certainty and stability.

It is illuminating to conclude this Part by considering the approach to regulatory change articulated by the Permanent Court of International Justice (PCIJ) in the Oscar Chinn Case, ${ }^{133}$ which has been cited by several investment treaty tribunals in holding that legitimate regulatory measures which negatively impacted an investment, without depriving the investor of control or

129 EnCana Corp v Ecuador, LCIA Case UN3481, UNCITRAL, Award (3 February 2006) para 173. See also para 177 .

130 ibid paras $174,177$.

131 Perenco v Ecuador (n 53) paras 685-89; Burlington (n 88) paras 430, 456-57; see also paras 391, 397, 404. This aspect of the Burlington award was subject to dissent, see Diss Op Arbitrator Orrego Vicuña, paras 21-27; The finding of expropriation in in Occidentalv Ecuador (No 2) (n 85) para 455 concerned Ecuador's termination of the Claimant's contract rather than its windfall profits tax. The Tribunal in Murphyv Ecuador (n 57) did not consider whether Ecuador's measures constituted an expropriation, see para 294.

132 El Paso (n 1) paras 245, 256, 297-99; Total (n 1) paras 196-99; LG\&E (n 65) paras 198-200; CMS (n 49) paras 263-64; National Grid v Argentina, UNCITRAL, Award (3 November 2008) para 154; BG Group v Argentina, UNCITRAL, Final Award (24 December 2007) paras $267-72$.

133 Oscar Chinn Case (UK/Belgium) PCIJ Rep Series A/B Case No 63. 
enjoyment of the investment, did not constitute indirect expropriations. ${ }^{134}$ In Oscar Chinn the United Kingdom contended that Belgium, by heavily subsidising the costs of state-owned transport companies in the Belgian Congo, in the context of decreased demand during the Great Depression, had violated its international obligations and caused damage to Mr Chinn, a UK national and competitor in the river transport business. While much of the UK's claim was based on a specific treaty regime providing for free trade and equality of treatment, the UK also submitted that Belgium 'by depriving indirectly Mr. Chinn of any prospect of carrying on his business profitably, constituted a breach of the general principles of international law, and in particular of respect for vested rights.' 135 The Court rejected this argument, emphasising that Mr Chinn did not possess 'a genuine vested right', as opposed to a customer base and 'the possibility of making a profit'. ${ }^{136}$ According to the PCIJ:

Favourable business conditions and goodwill are transient circumstances, subject to inevitable changes; ... No enterprise ... can escape from the chances and hazards resulting from general economic conditions. Some industries may be able to make large profits during a period of general prosperity ... but they are also exposed to the danger of ruin or extinction if circumstances change. ${ }^{137}$

In assessing the circumstances of the case, the Court showed sensitivity to the dire economic situation in which the measures had been adopted, and observed that private competitors to the partly state-owned transport provider had 'no claim to any guarantee of profits from the State.'138 Like most contemporary arbitral interpretations of the indirect expropriation norm, the PCIJ's Judgment reflects a qualified and social conception of property, whereby legitimate regulatory changes may damage the value of an investment without constituting an indirect expropriation. As in contemporary investment treaty arbitration, the PCIJ determined who should bear the costs of regulatory change: the foreign investor or the host state. ${ }^{139}$

$134 L G \& E$ (n 65) paras 197-200; Total (n 1) para 197, fn 232; See also El Paso (n 1) para 366 (citing Oscar Chinn as authority for the proposition that 'economic stability cannot be a legitimate expectation of any economic actor').

135 Oscar Chinn (n 133) 87.

136 ibid 88.

137 ibid.

138 ibid $78-79$.

139 Wälde and Kolo (n 117) 825. 
This article has sought to interrogate the various senses in which contemporary investment law raises questions of change. Its key contribution has been to distinguish between questions of change in international investment norms themselves, and changes in a host state's regulatory system which is subject to the control of such norms, and to explain how these different manifestations of change relate to the distinct, although interrelated, questions of the interpretation and application of investment standards. This framework was applied to the two most prominent and controversial international investment norms, the FET standard and the protection against indirect expropriation. This exposition demonstrated how the relative influence of arbitral tribunals and states differs markedly at the levels of interpretation and application. On questions concerning the interpretation of international investment norms, and potential changes in their meaning, arbitrators operate within wider processes of law-development and share interpretive authority with states as treaty masters. ${ }^{140}$ Over the past decade states have been extremely active in redrafting investment treaties to reduce arbitral discretion and increase their space for future changes in domestic regulation given the dynamic nature of contemporary policy challenges. While the treaty-based reforms reviewed in this article are unlikely to be entirely successful in removing ambiguity and arbitral discretion in the process of interpretation, current trends suggest states will in future take their role as treaty masters very seriously, for example by agreeing upon authoritative interpretations to counter undesired arbitral awards. Thus, if anything arbitrators' influence over developments in the content of international investment norms as a general matter, or questions of interpretation, appears set to decline.

However, investment norms are notoriously fact-specific. Arbitrators dominate the process of applying investment norms to specific investor-state disputes. This application function frequently requires arbitrators to decide upon the permissible margin of regulatory change within the host state. Such determinations go to the heart of the governance function performed by investment treaty arbitration in developing acceptable standards of host state conduct. ${ }^{141}$ So long as investment treaties provide investors with access to international arbitration against host states, arbitrators are likely to play a key role in manging change in this sense.

\footnotetext{
140 Roberts (n 3) 191.
}

141 See above $n$ 43. 
Stability and change are timeless concerns in international investment law. ${ }^{142}$ This article has provided conceptual clarity which helps us understand what is at stake when we speak of this tension, and the various senses in which it manifests itself in contemporary investment law. With the investment regime at a crossroads, it is quite possible we will see significant shifts in the content of investment norms as a general interpretive matter; in the degree of host state regulatory change arbitrators are willing to tolerate in specific disputes as they seek to arrive at more balanced decisions; and in the structural and institutional features of the regime.

$142 \operatorname{Martin}(\mathrm{n} 91) 38$. 